$52.8 \%$ over 2.0 years of exposure to GLM and $45.2 \%$ over 1.6 year of exposure to GLM-IV.

Conclusion: In this real-world study of Canadian patients with RA, differences in baseline characteristics between patients treated with an antiTNF over time and between agents shows potential selection biases when selecting a given therapy and may impact the proportion of patients achieving a target-specific outcome. Treatment significantly reduced disease activity and improved functionality in a similar fashion and were also safe and well tolerated.

Disclosure of Interests: Proton Rahman: None declared, Philip Baer Grant/research support from: Janssen sponsored study, Consultant for: Eli Lilly, Pfizer, Abbvie, Amgen, Merck, Novartis, Sanofi Genzyme, Paladin, Janssen, Johnson \& Johnson, Speakers bureau: Eli Lilly, Pfizer, Abbvie, Amgen, Janssen, Denis Choquette Grant/research support from: Abbvie, Amgen, Eli Lilly, Novartis, Pfizer, Sandoz, Consultant for: Abbvie, Amgen, Eli Lilly, Novartis, Pfizer, Sandoz, Speakers bureau: Abbvie, Amgen, Eli Lilly, Novartis, Pfizer, Sandoz, Rafat Faraawi: None declared, Louis Bessette Grant/research support from: Amgen, BMS, Janssen, Roche, UCB, AbbVie, Pfizer, Merck, Celgene, Sanofi, Lilly, Novartis, Consultant for: Amgen, BMS, Janssen, Roche, UCB, AbbVie, Pfizer, Celgene, Lilly, Novartis, Speakers bureau: Amgen, BMS, Janssen, Roche, UCB, AbbVie, Pfizer, Merck, Celgene, Lilly, Novartis, Milton Baker Grant/research support from: Janssen Sponsored Study, Raman Rai Consultant for: Janssen, Amgen, BMS, Roche, Abbvie, Pfizer, Merck, Novartis, Speakers bureau: Janssen, Amgen, Roche, BMS, Abbvie, John Kelsall Grant/research support from: Janssen Sponsored Study, Larissa Lisnevskaia Grant/research support from: Janssen Sponsored Study, Jodie Reis Grant/research support from: Janssen Sponsored Study, Keltie Anderson Grant/research support from: Janssen Sponsored Study, Wojciech Olszynski Grant/research support from: Janssen sponsored study, Emmanouil Rampakakis : None declared, Odalis Asin Mlilan Employee of: Employee of Janssen, Allen Lehman Employee of: Employee of Janssen, Meagan Rachich Shareholder of: Janssen, Employee of: Employee of Janssen, Francois Nantel Shareholder of: Janssen, Employee of: Employee of Janssen

DOI: 10.1136/annrheumdis-2019-eular.1460

\section{FRI0110 RITUXIMAB BIOSIMILAR NON-MEDICAL SWITCH - DOES IT WORK?}

Muhammad Khurram Nisar. Luton and Dunstable University Hospital, Rheumatology, Luton, United Kingdom

Background: Since the introduction of anti-TNF biosimilars in routine clinical practice, there has been a drive to implement the switch program for all biosimilars at the point of availability. Rituximab biosimilar was granted marketing authorisation by the EMA in February 2017. Our Trust was one of the first centres to embrace a CQUIN which required adoption of biosimilar within three months for new patients and one year for switchers. This could help deliver significant savings to the NHS whilst achieving similar clinical outcomes.

Objectives: We report our early experience of introducing rituximab biosimilar in people with RA.

Methods: A list of all patients prescribed rituximab was extracted through our database. A 'switch' letter was drafted and sent to all patients including Truxima information sheet. Patients were given the opportunity to contact nurse helpline for information or if disease control worsened/adverse effects developed. We reviewed all relevant records and collected data on any adverse events and disease outcome on either side of the switch. Patients were reviewed as originally planned by their respective clinicians.

Results: 44 patients with RA on $2 \mathrm{~g}$ dose six-monthly were identified established on rituximab. Four had stopped treatment prior to switching All 40 agreed to switch to Truxima that was completed by February 2018. Mean age of switchers was 58.6 (range 26-80 years). Eight were men and remaining $32(80 \%)$ were women. Fourteen (35\%) were Asian, one Afro-Caribbean and the rest $(62 \%)$ were White Caucasian.

DAS28 scores were available for all participants. Prior to the switch median DAS28 was 3.0 (range 0.6-5.1). Following the switch it was 2.95 (range 1.5-5.7). Amongst these, eight (20\%) reported adverse effects. Four had serum sickness reaction within the first week of the second dose with loss of efficacy. One required admission to ED (<24 hrs) for further management. All decided against further biosimilar and three were swapped back to the originator with no further concerns. In one case the clinician decided to change the class of drug to a TNF inhibitor. Three patients had mild intolerance and agreed to continue Truxima with no further issues. One patient developed miliary tuberculosis and was taken off biologic therapy.
Adverse events related to Rituximab biosimilar switch

\begin{tabular}{|c|c|c|c|c|c|c|}
\hline Age & Gender & $\begin{array}{c}\text { Previous } \\
\text { Mabthera } \\
\text { Cycles }\end{array}$ & $\begin{array}{l}\text { Prior } \\
\text { DAS28 }\end{array}$ & $\begin{array}{l}\text { Post } \\
\text { switch } \\
\text { DAS28 }\end{array}$ & Adverse effects & $\begin{array}{l}\text { Final } \\
\text { drug } \\
\text { choice }\end{array}$ \\
\hline 39 & $\mathrm{~F}$ & 1 & 3.5 & 5.1 & $\begin{array}{c}\text { Gen unwell, achy, flu like } \\
\text { symptoms }\end{array}$ & Humira \\
\hline 70 & M & 3 & 2.1 & 1.8 & Itchy scalp, brain fog & Truxima \\
\hline 49 & $\mathrm{~F}$ & 2 & 4.4 & 2.8 & Vomiting, diarrhoea & Mabthera \\
\hline 48 & $\mathrm{~F}$ & 2 & 3.1 & 5.5 & Palpitations, dizziness & Mabthera \\
\hline 48 & $\mathrm{~F}$ & 4 & 1.8 & 2.8 & Headache, flushing & Truxima \\
\hline 58 & $\mathrm{~F}$ & 4 & 4.5 & 5.1 & Nausea, flushing, headache & Truxima \\
\hline 37 & $\mathrm{~F}$ & 5 & 3.5 & 4.5 & $\begin{array}{l}\text { Body pains, headache, } \\
\text { distaste, lethargy } \\
\text { (hospitalised) }\end{array}$ & Mabthera \\
\hline 76 & $\mathrm{~F}$ & 1 & 2.2 & 2.5 & Miliary TB & $\begin{array}{c}\text { Biologic } \\
\text { withdrawn }\end{array}$ \\
\hline
\end{tabular}

Conclusion: Our experience of switching rituximab patients is certainly not as smooth as it was for infliximab and etanercept. All were happy to switch after receiving a letter and having the opportunity to contact if necessary. Substantial annual cost savings of nearly $£ 140,000$ were achieved once the switch process completed. At group level there were no major differences in disease outcomes. However, $10 \%$ had severe serum sickness reaction with loss of efficacy and loss of confidence in the drug. One patient developed military TB despite having one previous originator cycle with no issues. We support the routine switching from originator to biosimilar rituximab however close monitoring is required certainly in the first few weeks of dose administration.

Disclosure of Interests: Muhammad Khurram Nisar Grant/research support from: Muhammad Nisar undertakes clinical trials and received suppor (including attendance at conferences, speaker fees and honoraria) from Roche, Chugai, MSD, Abbvie, Pfizer, BMS, Novartis, Celgene, Mallinckrodt, UCB and Lilly, Consultant for: Muhammad Nisar undertakes clinical trials and received support (including attendance at conferences, speake fees and honoraria) from Roche, Chugai, MSD, Abbvie, Pfizer, BMS Novartis, Celgene, Mallinckrodt, UCB and Lilly, Speakers bureau: Muhammad Nisar undertakes clinical trials and received support (including attendance at conferences, speaker fees and honoraria) from Roche Chugai, MSD, Abbvie, Pfizer, BMS, Novartis, Celgene, Mallinckrodt, UCB and Lilly

DOI: 10.1136/annrheumdis-2019-eular.140

\section{FRI0111 ASSOCIATION BETWEEN RHEUMATOID FACTOR STATUS AND DISCONTINUATION OF TUMOR NECROSIS FACTOR INHIBITORS DUE TO INEFFECTIVENESS IN RHEUMATOID ARTHRITIS}

Yoshikazu Ogawa ${ }^{1}$, Nobunori Takahashi ${ }^{2}$, Toshihisa Kojima ${ }^{2}$, Naoki Ishiguro ${ }^{2}$. ${ }^{1}$ Nakatsugawa Municipal General Hospital, Nakatsugawa, Japan; ${ }^{2}$ Nagoya University Graduate School of Medicine, Nagoya, Japan

Background: As for the treatment of rheumatoid arthritis (RA), the influence of rheumatoid factor (RF) positivity on the long-term efficacy of tumor necrosis factor inhibitors (TNFi) is controversial.

Objectives: We conducted an exploratory study in a large cohort of RA patients to evaluate the relationship between RF status and the discontinuation of TNFi treatment due to ineffectiveness in a clinical setting.

Methods: This study included bio-naïve RA patients enrolled in the Tsurumai Biologic Communication Registry in Japan. The crude comparison of TNFi discontinuation due to ineffectiveness between seropositive and seronegative patients was analyzed using the cumulative incidence function of competing events and Gray test. We assessed the associations between baseline patient characteristics and discontinuation of TNFi therapy due to insufficient response using Fine-Gray proportional hazard regression. Fine-Gray proportional hazard analysis considered competing events of interest, including insufficient response, adverse event, palliation, and personal reasons.

Results: Demographic and clinical characteristics of each group are described in Table 1. There was a higher discontinuation rate due to insufficient response in RF positive patients than in RF negative patients using Gray test (Figure). RF positivity was significantly predictive of the discontinuation of TNFi therapy due to ineffectiveness using Fine-Gray proportional hazard regression analysis after adjusting for baseline characteristics, including age, sex, stage, class, disease activity at baseline, methotrexate use, and prednisolone use (Table 2). 